\title{
Publisher Correction: Spatio-temporal variability of processes across Antarctic ice-bed-ocean interfaces
}

\author{
Florence Colleoni', Laura De Santis², Christine S. Siddoway (i) ${ }^{3}$, Andrea Bergamasco ${ }^{4}$, Nicholas R. Golledge (i) ${ }^{5,6}$, \\ Gerrit Lohmann 7,8 , Sandra Passchier (10 ${ }^{9}$ \& Martin J. Siegert (10 ${ }^{10}$
}

Correction to: Nature Communications; https://doi.org/10.1038/s41467-018-04583-0; published online 18 June 2018

The original version of this Article contained an error in the spelling of the author Florence Colleoni, which was incorrectly given as Florence Colloni. This has been corrected in both the PDF and HTML versions of the Article.

Published online: 11 July 2018

\begin{abstract}
(c) (i) Open Access This article is licensed under a Creative Commons Attribution 4.0 International License, which permits use, sharing, adaptation, distribution and reproduction in any medium or format, as long as you give appropriate credit to the original author(s) and the source, provide a link to the Creative Commons license, and indicate if changes were made. The images or other third party material in this article are included in the article's Creative Commons license, unless indicated otherwise in a credit line to the material. If material is not included in the article's Creative Commons license and your intended use is not permitted by statutory regulation or exceeds the permitted use, you will need to obtain permission directly from the copyright holder. To view a copy of this license, visit http://creativecommons.org/licenses/by/4.0/.
\end{abstract}

(C) The Author(s) 2018

\footnotetext{
${ }^{1}$ Fondazione Centro Euro-Mediterraneo sui Cambiamenti Climatici, 40129 Bologna, Italy. ${ }^{2}$ Istituto Nazionale di Oceanografia Sperimentale, 34010 Sgonico, Italy. ${ }^{3}$ Department of Geology, Colorado College, Colorado Springs, CO 80903, USA. ${ }^{4}$ Centro Nazionale delle Ricerche - Istituto di Scienze Marine, 30122 Venice, Italy. ${ }^{5}$ Antarctic Research Centre, Victoria University of Wellington, Wellington 6140, New Zealand. ${ }^{6}$ GNS Science, Avalon, Lower Hutt 5010 , New Zealand. ${ }^{7}$ Alfred Wegener Institute, Helmholtz Centre for Polar and Marine Research, 27570 Bremerhaven, Germany. ${ }^{8}$ University of Bremen, 28359 Bremen, Germany. ${ }^{9}$ Department of Earth and Environmental Studies, Center for Environmental and Life Sciences, Montclair State University, Montclair, NY 07043, USA. ${ }^{10}$ Grantham Institute and Department of Earth Science and Engineering, Imperial College of London, London SW7 2AZ, UK. Correspondence and requests for materials should be addressed to F.C. (email: flocolleoni@gmail.com)
} 